\title{
RESPONSE OF TOMATO PLANTS TO LOW PLASTIC-ZNO NANO-COMPOSITE TUNNELS COVERING AND CHITOSAN NANOPARTICLES FOLIAR SPRAYING \\ Shams, A. S. ${ }^{1}$ and Nahla M. Morsy ${ }^{2}$
}

1. Horticulture Department, Faculty of Agriculture, Benha University, Moshtohor, 13736 Kaliobya, Egypt.

2. Sustainable Development of Environment and Management its Projects Department, Environmental Studies \& Research Institute (ESRI), EL-Sadat City University.

E-mail correspondance: Abdelhakeem.Shams@fagr.bu.edu.eg

Mobil: +2 01224580048

\begin{abstract}
A field experiment was conducted for two successive winter seasons of $2012 / 2013$ and 2013/2014 in the farm of the Faculty of Agriculture, Moshtohor, Benha University, Egypt, to explore the effects of treating the plastic tunnels with $\mathrm{ZnO}$ nanoparticles on the growth parameters, yield and its quality of tomato (Lycopersicon esculentum Mill cv. Super Strain B). It also investigates the effects of using the foliar application of chitosan nanoparticles applied at 0.5 and $1 \%$ versus the commercial chitosan applied at the same rates on the growth parameters and the yield of tomatoes and whether these treatments could be positively/negatively affected by treating the plastic tunnels with $\mathrm{ZnO}$ nanoparticles. Results revealed that the tomato plants grown under nano-composite covering (PE with nano-ZnO) gave rise to vigor growth, higher yield and fruit quality compared with the tomato plants under low plastic tunnel (PE without nano-ZnO). Chitosan nanoparticles $(0.5$ or $1 \%)$ increased the plant growth (plant height, fresh, dry weight and leave area), early and total yield per plant and per feddan and average fruit weight beside of improving the quality of fruits (vitamin C, acidity and total sugars) than all other treatments. Thus, using chitosan nano particles ( 0.5 or $1 \%$ ) under nano-composite covering (PE with nano$\mathrm{ZnO}$ ) is the recommended practice to attain good growth parameters and achieve early and high total yield with better quality of tomato fruits. However, the low concentration of chitosan nano-particles achieves the highest return economist in this case.
\end{abstract}

Keywords: Tomato, Chitosan, Low plastic tunnels, polyethylene (PE), Nano-ZnO, Feddan (fed. $=4200 \mathrm{~m}^{2}$ )

\section{INTRODUCTION}

Tomato (Lycopersicon esculentum Mill) is an important crop worldwide. It has high nutritional valuese .g. a source of different classes of the antioxidants such as carotenoids, ascorbic acid, phenolic compounds, and $\alpha$ tocopherol (Abushita et al., 1997; Beecher, 1998).Many products of tomato are used in kitchens e.g. ketchup, juice...etc(Tahir et al., 2012). Thus, tomato is considered an important crop in many markets around the world. However, the cost-price and the quality are still considered the important challenge (Wijnands, 2003).

Plastic films are employed as coverings for greenhouses or tunnels over crop rows (Lamont, 2009; Riggi et al., 2011) to attain high crop yield all the year around beside of the effective use of fertilizers, and water resources under the greenhouses(Pardossi et al., 2004). The optical properties of the 
traditional used plastic films determine the amounts of solar radiation that reaches theplants (Ham et al., 1993; Heißner et al., 2005).Ultraviolet (UV) radiations is considered harmful to plants and soil living organisms(HolloÂsy, 2002) and accelerates degradation of the plastic films(Kyrikou and Briassoulis, 2007). Visible light is required for the photosynthetic activity in plants(Wang et al., 2009), thus high transparency in this range is required in plastic films to increase crop production. Infrared (IR) radiation heats up the greenhouse(Hoffmann and Waaijenberg, 2002); therefore, high IR opacity preserves heat during night time and saves energy especially during the cold winter seasons (Espi, et al., 2006).

Several oxides and minerals in micrometric size have been used to improve the thermal efficiency of the greenhouse cover films; nevertheless, loss of transparency and film photo-degradation could happen (Espi, et al., 2006). The use of these oxides in the nano-scale provide UV shielding without affecting the transparency of the used films(Druffel et al., 2008).Zinc oxide introduced high ultraviolet-shielding capability preserving transparency (Espejo et al, 2012) by more than $95 \%$ of total UV transmission (Espejo et al, 2012). Moreover, such nano-technology can improve the mechanical properties of the polymeric materials. i.e increase the material modulus to attain higher bigger mechanical resistance or elongation (Balazs et al., 2006 and Tjong 2006).

Chitosan, a given name to the deacetylated form of chitin, is a natural biodegradable compound derived from crustaceous shells such as crabs and shrimps (Rinaudo, 2006; Baker et al., 2007). It is a low acetyl form of chitin mainly composed of glucosamine, 2 -amino-2- deoxy- $\beta$-D-glucose (Freepons, 1991). Chitosan is characterized by its polycationic nature (Bautista-Baños et al., 2006), which candidate this polymer to improve plant protection (ElHadrami et al., 2010) and (Terry and Joyce, 2004). Moreover, the degraded chitin can be used as an efficient nitrogen source(Geisseler et al., 2010). Thus, chitosan treatment has been shown to stimulate plant growth (Kim, 2005) and improve storability of postharvest fruits and vegetables (El Ghaouth et al., 1991). In this concern, the nanoparticles of chitosan could guarantee more uniform distribution of the spray and higher effectiveness on plants.

The current research aimed at studying the effects of growing tomatoes under low tunnels treated with $\mathrm{ZnO}$ nanoparticles during two successive winter seasons. This study also investigates the effect of spraying plants with chitosan nanoparticle as a tonic on the plant growth performance, yield quantity and quality. This study also measures the outcome economical returns of this study.

\section{MATERIALS AND METHODS}

Materials of study

Chitosan: a commercial product (contains 90-95\% chitosan) was supplied by Oxford Laboratory, India. Chitosan nanoparticles processed using the method described by Corradini et al. (2010). Nano-zinc oxide (ZnO, $20 \mathrm{~nm}$ ), was provided by Nanotech Egypt for Photo-electronics, Bahgat group, 6 October region, Giza Governorate. Transparent low plastic tunnel of 
$70 \mathrm{~cm}$ height, $220 \mathrm{~cm}$ width and $70 \mu$ thickness was obtained from Hyma plastic (22, El-Obour Buildings - Salah Salem St., in front of Panorama October, Cairo, Egypt). Soil samples $(0-30 \mathrm{~cm})$ were collected from the experimental farm of the Faculty of Agriculture, Moshtohor, Benha University, Qalubiya Governorate, Egypt prior to seedling transplanting and analyzed for their physical and chemical properties as outlined by Jackson (1969). Physical and chemical properties of the investigated soil are shown in Table 1.

Table 1: Physical and chemical properties of the soil under study before transplanting

\begin{tabular}{|c|c|c|c|c|c|c|c|c|c|c|}
\hline \multicolumn{4}{|c|}{ Soil texture } & \multirow{3}{*}{$\mathrm{pH}$} & \multirow{3}{*}{$\begin{array}{c}E C \\
\left(\mathrm{dS} \mathrm{m}^{-1}\right)\end{array}$} & \multirow{3}{*}{$\begin{array}{l}\text { O.M } \\
(\%)\end{array}$} & \multirow{3}{*}{$\begin{array}{c}\mathrm{CaCO}_{3} \\
(\%)\end{array}$} & \multirow{2}{*}{\multicolumn{3}{|c|}{$\begin{array}{c}\text { Soil available } \\
\text { macronutrients }\left(\mathrm{mg} \mathrm{kg}^{-1}\right.\end{array}$}} \\
\hline Sand & Silt & Clay & Tavtur & & & & & & & \\
\hline$(\%)$ & (\%) & $(\%)$ & rexture & & & & & $\mathrm{N}$ & $\mathrm{P}$ & $\mathrm{K}$ \\
\hline 24.4 & 24.6 & 51 & Clay loam & 7.9 & 2.16 & 1.41 & 1.53 & 22.5 & 9.1 & 120 \\
\hline
\end{tabular}

\section{The field study}

This experiment was carried out during the winter seasons of the two successive seasons of 2012/2013 and 2013/2014 at the Experimental Farm, Faculty of Agriculture, Moshtohor, Benha University to study the effect of the use of chitosan and chitosan nanoparticles at 5 and $10 \mathrm{~g} \mathrm{~L}^{-1}$ on vegetative growth parameters, fruit yield and its quality of tomato (Lycopersicon esculentum Mill cv. Super Strain B) grown under low plastic tunnels (PE or PE with $\mathrm{ZnO}$ nanoparticles, $20 \mathrm{~nm}, 20 \mathrm{mg} / \mathrm{m}^{2}$ ) under drip irrigation system. Tomato plants were transplanted on $15^{\text {th }}$ of November during the two growing seasons. The experimental treatments were arranged in a split plot design and included ten treatments with three replicates as represented in Table 2.

Table 2: Experimental design

\begin{tabular}{|l|l|}
\hline Treatments & Description \\
\hline & Under low plastic tunnels (polyethylene, PE) \\
\hline T1 & The control treatment (spray with distilled water). \\
\hline T2 & Chitosan at $0.5 \%$ \\
\hline T3 & Chitosan at $1 \%$. \\
\hline T4 & Chitosan nanoparticles at $0.5 \%$. \\
\hline T5 & Chitosan nanoparticles at $1 \%$. \\
\hline & Under low plastic tunnels (PE with ZnO nanoparticles) \\
\hline T6 & The control treatment (spray with distilled water). \\
\hline T7 & Chitosan at $0.5 \%$. \\
\hline T8 & Chitosan at $1 \%$. \\
\hline T9 & Chitosan nanoparticles at $0.5 \%$. \\
\hline
\end{tabular}

Each experimental plot included one ridge $1.2 \mathrm{~m}$ wide and $5 \mathrm{~m}$ long. Seedlings were selected and transplanted on two sides of the ridge and $30 \mathrm{~cm}$ apart, $60 \mathrm{~cm}$ between ridges and plot area was $9 \mathrm{~m}^{2}$ and each plot contained 32 plants. Nitrogen $\left(\mathrm{NH}_{4} \mathrm{NO}_{3}, 33.5 \% \mathrm{~N}\right)$, phosphorus $\left(\mathrm{Ca}\left(\mathrm{H}_{2} \mathrm{PO}_{4}\right)_{2} \cdot \mathrm{CaCO}_{3}\right.$, $\left.16 \% \mathrm{P}_{2} \mathrm{O}_{5}\right)$ and potassium $\left(\mathrm{K}_{2} \mathrm{SO}_{4}, 48 \% \mathrm{~K}_{2} \mathrm{O}\right)$ were used in this study. Fertilizers were added to all plots at rates of $160 \mathrm{~kg} \mathrm{~N} \mathrm{fed}^{-1}, 64 \mathrm{~kg} \mathrm{P}_{2} \mathrm{O}_{5} \mathrm{fed}^{-1}$ and $48 \mathrm{~kg} \mathrm{~K} \mathrm{~K}_{2} \mathrm{Ofed}^{-1}$, respectively. Phosphate fertilizer was added for 
experimental plots during soil preparation, while $\mathrm{NH}_{4} \mathrm{NO}_{3}$ and $\mathrm{K}_{2} \mathrm{SO}_{4}$ fertilizer were added weekly within the drip irrigation system.

\section{Data recorded}

a) Vegetative growth characters.

Five plants were taken from each plot randomly (90 days after transplanting) and plant height, leaf area per plant and total fresh and dry weight per plant were recorded.

b) Fruit yield and its components.

1. Early yield per plant and per fed. (The sum of the first three pickings).

2. Total yield per plant and per fed.(All harvested fruit from each plot along the harvesting season were weighted and calculated as total fruit yield).

3. Average fruit weight.

c) Chemical constituents of fruits

1. Reducing, non-reducing and total sugars were determined according to the method of Shaffer and Hartman (1921).

2. Vitamin $C$ and acidity were determined according to A.O.A.C. (2000)

Statistical analysis:

All obtained data were recorded on plot basis and statistically analyzed according to a split plot design. Duncan's Multiple Range Test at $5 \%$ level was used to compare between significant treatments means. All the obtained data were subjected to statistical analysis of variance according to the procedure outlined by Steel et al.(2006). MSTAT-C program (1988) was used for statistical computations.

\section{RESULTS}

Effect of low plastic-Zn Onano-composite tunnels covering and chitosan nanoparticles foliar spraying on plant vegetative growth parameters

Data in Table 3 show the effects of using the two types of low plastic tunnels on the growth parameters of tomato plants. In general, using nanocomposite of low plastic-ZnO tunnels increased the plant growth parameters (plant height, fresh and dry weight of plant as well as leave area).

Also, foliar application with chitosan nanoparticles type generally gave the highest values of plant growth parameters comparing with commercial type of chitosan under normal low plastic tunnel. Finally, it could be concluded that supplying with chitosan as a foliar application with different types and concentrations used in this experiment gave the highest value of vegetative growth (plant height, fresh and dry weight/plant) under nano-composite of low plastic-ZnO tunnel, but the same type of low tunnel supplying with chitosan at $1 \%$ concentration gave the highest leaves area comparing with other treatments in both seasons.

Effect of low plastic-ZnO nano-composite tunnels covering and chitosan nanoparticles foliar spraying on the tomato yield

Data recorded in Table 4reveal thatusing nano-composite of low plastic-ZnO tunnels increased the average weight of the tomato fruitsand both theearly and total fruit yield of tomatoes. 
J. Plant Production, Mansoura Univ., Vol. 5 (9), September, 2014

$3+4$ 
Chitosan foliar application under nano-ZnO treated tunnels increased the plant fruit weight. However, the form and the concentrations didn't give rise to any further significant increases. Concerning the early and total yields, increasing the concentrations of chitosan resulted in further increases in tomato yields. Application of chitosan nanoparticles increased tomato early and total yieldsper plant and per feddan. However, increasing the concentration seemed to be insignificant for increasing tomato yields. Also, the foliar application of chitosan nanoparticles in both concentrations $(0.5$ or 1 $\%)$ gave the highest early and total yield per plant and per feddan with significant differences in comparing with commercial chitosan under two types of low plastic tunnels and in both seasons.

\section{Effect of low plastic-ZnO nano-composite tunnels covering and} chitosan nanoparticles foliar spraying on the quality of tomato fruits

Data in Table 5 show that foliar application with chitosan under low plastic-ZnO nano-composite tunnels improved the quality of tomato fruits, Chitosan nanoparticles gave the best quality of tomato fruits in terms of vitamin-C, acidity reducing and non-reducing sugars with no significant differences between the two rates $(0.5$ and $1.0 \%)$ of application. However, total sugar was the only parameter that increased with increasing the application rate of chitosan nanoparticles from 0.5 to $1.0 \%$.

While, the foliar application with commercial chitosan increased vitamin-C, acidity and reducing sugars, meanwhile no significant effects were detected for increasing the rate of chitosan application. Concerning non-reduced and total sugars, increasing the rate of commercial chitosan resulted in further improvements in the quality of the tomato fruits.

\section{Economic evaluation:}

It is clear from data presented in Table 6 that production coasts increased under nano-composite of low plastic- $\mathrm{ZnO}$ tunnels and net return was high in this case. Also use foliar spray with chitosan increase cost but also improves the growth and maximize productivity. On the other hand, treatments without chitosan foliar spray showed the lowest value of net return.While, the foliar application of chitosan nanoparticles in both concentrations $(0.5$ and $1 \%)$ gave the highest early and total yield per plant and per feddan under two types of low plastic tunnels used in this study in both seasons (Table, 4). So that, from the previous results using chitosan nanoparticles at $0.5 \%$ concentration is more economically than using it at $1 \%$ for obtaining highest early and total yield. That was cleared in the economic return of the treatment, which has been foliar spraying of plants with chitosan nano particles, $0.5 \%$ under low plastic- $\mathrm{ZnO}$ nano-composite tunnels (Table, 6). Which was the net return is 31868 LE as an average in both seasons. 
J. Plant Production, Mansoura Univ., Vol. 5 (9), September, 2014

5

1539 
Shams, A. S. and Nahla M. Morsy 


\section{DISCUSSION}

Using nano-composite of low plastic-ZnO tunnels increased plant growth parameters, average weight of the fruits, early and total yield of tomatoes beside of improving the quality of the tomato fruits. Probably, $\mathrm{ZnO}$ nanoparticles improved the physical properties of plastic tunnel for protecting plants from cooling injury at low temperature condition e.g. increasing the benefit of infrared rays and low penetration of ultraviolet rays according to Espejo et al. (2012). Many investigators reported that using chitosan as foliar spray increased vegetative growth, yield and quality of vegetable crops (Abdel-Mawgoud et al., 2010; Ghoname et al., 2010 and Fawzyetal.,2012). The results obtained therein, reveal that chitosan application under nano-ZnO treated tunnels resulted in further significant increases in plant growth parameters and tomato yield quantity and quality. Similar results were reported on tomato (Shafshak et al., 2008) and strewberry (Abdel-Mawgoud et al., 2010). They attributed such effects to the constituents of the chitosan which comprises amino acids, vitamins, antioxidants, mineral constituents, poly saccharide. Such constituents play significant roles in cell formation, cell division and elongation, consequently increased the plant growth. Nanoparticles of chitosan seemed to be more effective in improving plant growth parameters, yield quantity and quality. These particles (diameter $<30$ $\mathrm{nm}$ ) enter directly into plant leaves through stomata (Grover et al., 2012) resulting in further improvements in plant growth (Abdel-Mawgoud et al., 2010). Increasing the concentration of chitosan nanoparticles increased tomato early and total yields; however, such increases were insignificant. Thus, using chitosan nanoparticles at $0.5 \%$ concentration is considered more economically than using it at $1 \%$ for obtaining highest early and total yield. It is worthy to mention that the effect of chitosan on plant growth and tomato yield seemed to be minimal under the normal low plastic tunnels not-treated with $\mathrm{ZnO}$ nano particles. Probably chitosan undergoes degradation with UV radiation(Wasikiewicz et al., 2005).

\section{CONCLUSION}

In conclusion, treating the plastic tunnels with $\mathrm{ZnO}$ nanoparticles could significantly improve the plant growth performance and the yield of tomatoes grown under plastic tunnels. Moreover, such a treatment can improve the effectiveness of chitosan on the growth of tomatoes. However, special concerns should be considered for the nano-applications of chitosan as effective treatment for improving the entry of chitosan into leaf stomata and could be considered economically when considering lower concentrations to attain high yield production.

Acknowledgement

This work was supported by Dr. Hoda Hafez, Prof. of NanoPhotochemistry, Environmental Studies \& Research Institute (ESRI), University of El-Sadat City, Egypt. 


\section{REFERENCES}

A.O.A.C. 2000. Official method of analysis. AOAC International $17^{\text {th }}$ ed. Maryland, USA: Association of Official Agricultural Chemists.

Abdel-Mawgoud, A.M.R., A.S. Tantawy, M.A. El-Nemr and Y.N. Sassine 2010. Growth and yield responses of strawberry plants to chitosan application. European J. Scientific Research, 39(1): 170- 177.

Abushita, A. A., E. A. Hebshi, H. G. Daood and P. A. Biacs 1997. Determination of antioxidant vitamins in tomatoes. Food Chem., 60: 207-212.

Baker, L. G., C. A. Specht, M. J. Donlin and J. K. Lodge 2007. Chitosan, the Deacetylated Form of Chitin, Is Necessary for Cell Wall Integrity in Cryptococcus neoformans[down-pointing small open triangle]. Eukaryot Cell, 6(5): 855-867. doi: 10.1128/EC.00399-06

Balazs, A.C., T. Emrick and T.P. Russell 2006. Nanoparticle polymer composites: Where two small worlds meet. Science; 314(5802): 11071110.

Bautista-Baňos, S., A.N. Hernández-Lauzardo, M.G. Velázquez-del Valle, M. Hernández-Lopez, E. Ait Barka, E. Bosquez-Molina and C.L. Wilson 2006. Chitosan as potential natural compounds to control pre and postharvest diseases of horticultural commodities. Crop. Prot., 25, pp. 108-118.

Beecher, G. R. 1998. Nutrient content of tomatoes and tomato products. Proc. Soc. Exp. Biol. Med., 218: 98-100.

Chapman, H. D. and P. F. Pratt 1961. Methods of analysis for soils, plants and waters. University of California, Berkeley, Division of Agricultural Sciences. 309 pp.

Corradini, E., M. R. de Moura and L. H. C. Mattoso 2010. A preliminary study of the incorparation of NPK fertilizer into chitosan nanoparticles. Express Polymer Letters, 4 (8): 509-515.

Druffel, T., O. Buazza and M. Lattis 2008. The role of nanoparticles in visible transparent nanocomposites. In: Gaburro Z, Cabrini S and Talapin D, (eds). Nanotechnology applications in coatings. San Diego, CA, pp. 70300-70309.

El Ghaouth, A., J. Arul, R. Ponnampalam and M. Boulet 1991. Chitosan coating effect on storability and quality of fresh strawberries. J. Food Sci., 56: 1618-1620.

El-Hadrami, A., L.R. Adam, I. El-Hadrami and F. Daayf 2010. Chitosan in Plant Protection. Mar. Drugs 8, 968-987.

Espejo, C., A. Arribas, F. Monzó and P. Diez 2012. Nanocomposite films with enhanced radiometric properties for greenhouse covering applications. Journal of Plastic Film and Sheeting, 28(4): 337-350. http://jpf.sagepub.com/content/28/4/336

Espi, E, A. Salmero' $n$ and A. Fontecha 2006. New ultra thermic films for greenhouse covers. J Plast Film Sheet; 22(1): 59-68. 
Fawzy, Z.F., Z.S. El-Shal, Li Yunsheng, Ouyang Zhu and Omaima M. Sawan 2012. Response of Garlic (Allium sativum, L) plants to foliar spraying of some bio-stimulants under sandy soil condition. J.Applied Scie. Res., 8(2): 770-776.

Freepons, D. 1991. Chitosan, does it have a place in agriculture? Proceedings of the Plant Growth Regulation Society of America, pp. 11-19.

Geisseler, D., W. R. Horwath, R. G. Joergensen and B. Ludwig 2010. Pathways of nitrogen utilization by soil microorganisms $-A$ review. Soil Biology and Biochemistry, 42(12): 2058-2067. doi: http://dx.doi.org/10.1016/j.soilbio.2010.08.021

Ghoname, A.A, M.A. El-Nemr, A.M.R. Abdel-Mawgoud and W.A. El-Tohamy 2010. Enhancement of sweet pepper crop growth and production by application of biological, organic and nutritional solutions. Research $\mathrm{J}$. Agric. Biological Scie., 6(3): 349-355.

Grover, M., S. Singh and B. venkateswarlu 2012. Nanotechnology: scope and limitions in agriculture. International J. Nanotechnology application, 2: 10-38.

Ham, J. M., G. J. Kluitenberg and W. L. Lamont 1993. Optical Properties of Plastic Mulches Affect the Field Temperature Regime. J. Amer Soc Hort Sci., 118(2): 188-193.

Heißner, A., S. Schmidt and B. von Elsner 2005. Comparison of plastic films with different optical properties for soil covering in horticulture: test under simulated environmental conditions. J. the Scie. Food Agric., 85(4): 539-548.

Hoffmann, S. and D. Waaijenberg 2002. Tropical and subtropical greenhouses-a challenge for new plastic films. Acta Hort., 578: 163169.

HolloÂsy, F. 2002. Effects of ultraviolet radiation on plant cells. Micron, 33: 179-197.

Jackson, M. L. 1969. Soil chemical analysis - advanced course ( $2^{\text {nd }}$ edition). Published by the author, Dep. of Soil Science, Univ. of Wisconsin, Madison, WI.

Kim, H.J. 2005. Characterization of bioactive compounds in essential oils, fermented anchovy sauce, and edible plants, and, induction of phytochemicals from edible plants using methyl jasmonate (MeJA) and chitosan. Ph.D Thesis, Clemson University, USA, 178 pp.

Kyrikou, I. and D. Briassoulis 2007. Biodegradation of Agricultural Plastic Films: A Critical Review. J Polym Environ 15: 125-150.

Lamont, W.J. 2009. Overview of the Use of High Tunnels Worldwide. HortTechnology 19: 25-29.

MSTAT-C. 1988. A micro-computer program for the design, management, and analysis of agronomic research experiments. Michigan State Univ., East Lansing, Ml.

Pardossi, A., F. Tognoni and L. Incrocci 2004. Mediterranean greanhouse technology. Chronica Horti., 44(2): 28-34. 
Riggi, E., G. Santagata and M. Malinconico 2011. Bio-Based and Biodegradable Plastics for Use in Crop Production. Recent Patents on Food,,nutrition \& Agriculture, 3(1): 49-63.

Rinaudo, M. 2006. Chitin and chitosan: Properties and applications .Progress in Polymer Science, 31(7): 603-632. doi:http://dx.doi.org/10.1016/j.progpolymsci.2006.06.001

Shaffer, P. A. and A. F. Hartman 1921. The iodometric determination of copper and its use in sugar analysis. J. Biol. Chem., 45: 390.

Steel, R.G.D., J.H. Torrie and D.A. Dickey 2006. Principles and Procedures of Statistics: A Biometrical Approach ( $3^{\text {rd }}$ ed.) New York: McGraw-Hill.

Shafshak, Nadia. S., S.M. Eid, H.S. Khafaga and Y.A.M. Salama 2008. Improving growth and productivity of tomato under saline conditions by fertilization and salinity hardening. J. Agric. Sci., Mansoura Univ., 33(11): 7803-7815.

Tahir, A., H. Shah, M. Sharif, W. Akhart and N. Akmal 2012. An overview of tomato economy of Pakistan:comparative analysis. Pakistan J. Agric. Res. 25.

Terry, L.A. and D.C. Joyce 2004. Elicitors of induced disease resistance in postharvest horticultural crops: a brief review. Postharvest Biology and Technology, 32: 1-13.

Tjong, S.C. 2006. Structural and mechanical properties of polymer nanocomposites. Mater Sci Eng: R: Rep;53 (3-4): 73-197.

Wang, X., K. Maeda, A. Thomas, K. Takanabe, G. Xin, J.M. Carlsson, K. Domen and M. Antonietti 2009.A metal-free polymeric photocatalyst for hydrogen production from water under visible light. Nat Mater 8: 76-80.

Wasikiewicz, J.M., F. Yoshii, N. Nagasawa, R.A. Wach and H. Mitomo 2005. Degradation of chitosan and sodium alginate by gamma radiation, sonochemical and ultraviolet methods. Radiation Physics and Chemistry 73: 287-295.

Wijnands, J. 2003. The international competitivenes of fresh tomatoes, peppers and cucumbers. Acta Hort 611. 


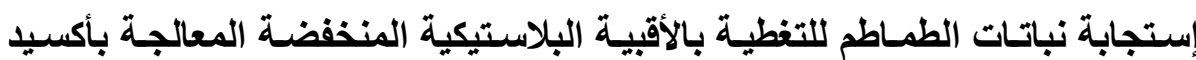

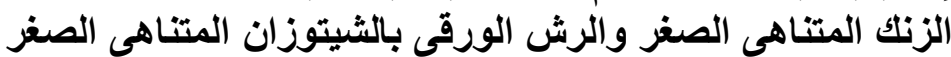

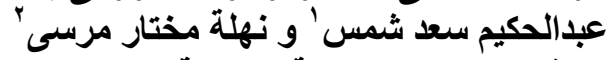

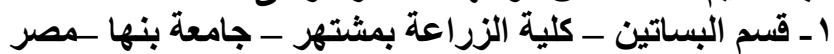

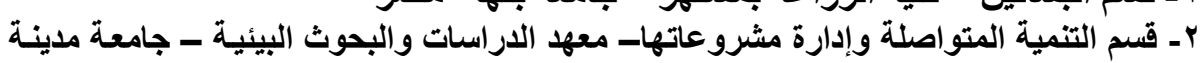
السادات - مصر الكئة

E-mail correspondance: Abdelhakeem.Shams@fagr.bu.edu.eg, Mobil: +2 01224580048

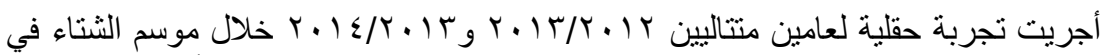

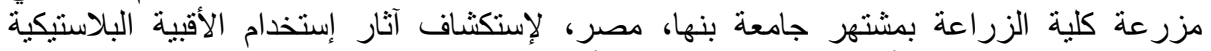

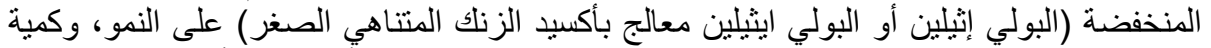

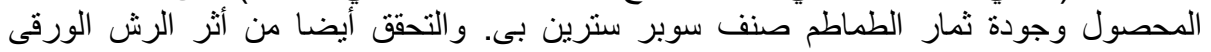

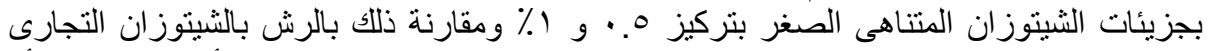

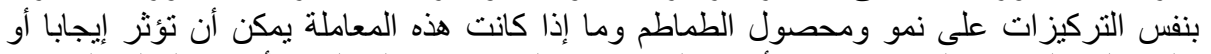

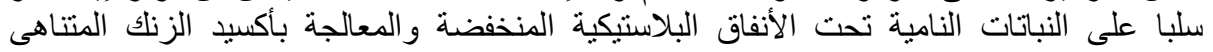

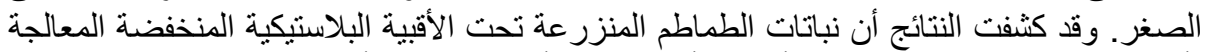

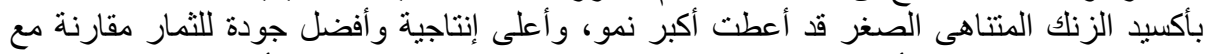

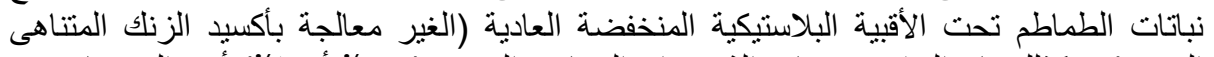

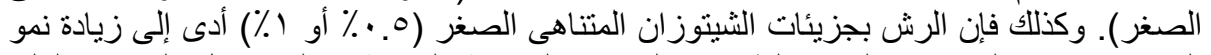

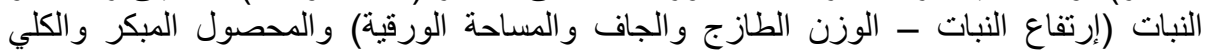

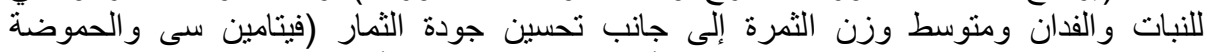

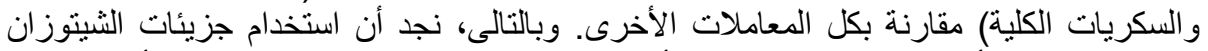

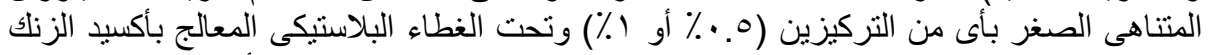

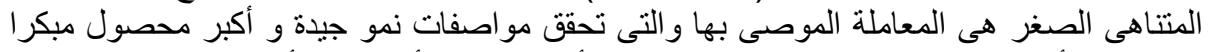
و ولي مع أفضل جودة لثمار نباتات الطماطم، إلا أن التركيز الأقل يحقق أعلى عائد إقتصادى في أنى

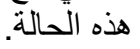

الكلمات الدالة: الطماطم ، الثينوزان، الأقبية البلاستيكية المنخفضة ، البولي إيثيلين ، أكسيد الزنك

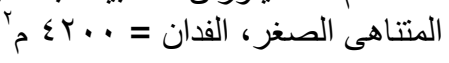


Table 3: Effects of low plastic-ZnO nano-composite tunnels covering and chitosan nanoparticles foliar spraying on the plant growth parameters of tomato, during the winter seasons of 2012/2013 and 2013/2014.

\begin{tabular}{|c|c|c|c|c|c|c|c|c|c|}
\hline & \multirow[b]{2}{*}{ Treatments } & \multicolumn{2}{|c|}{$\begin{array}{l}\text { Plant height } \\
(\mathrm{cm})\end{array}$} & \multicolumn{2}{|c|}{$\begin{array}{l}\text { Fresh weight } \\
\text { (g/plant) }\end{array}$} & \multicolumn{2}{|c|}{$\begin{array}{l}\text { Dry weight } \\
\text { (g/plant) }\end{array}$} & \multicolumn{2}{|c|}{$\begin{array}{l}\text { Leave area } \\
\text { (cm²/plant) }\end{array}$} \\
\hline & & \begin{tabular}{|c|}
$1^{\text {sl }}$ \\
season \\
\end{tabular} & $\begin{array}{c}2^{\text {na }} \\
\text { season }\end{array}$ & $\begin{array}{c}1^{\text {st }} \\
\text { season }\end{array}$ & $\begin{array}{c}2^{\text {na }} \\
\text { season }\end{array}$ & $\begin{array}{c}1^{\text {st }} \\
\text { season }\end{array}$ & $\begin{array}{c}2^{\text {na }} \\
\text { season }\end{array}$ & $\begin{array}{c}1^{\text {st }} \\
\text { season }\end{array}$ & $\begin{array}{r}2^{\text {nic }} \\
\text { seasc }\end{array}$ \\
\hline \multirow{5}{*}{ 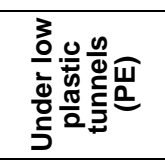 } & The control treatment (spray with distilled water) & $47.13 \mathrm{~cd}$ & $45.33 \mathrm{~d}$ & $179.12 \mathrm{~d}$ & $169.15 f$ & $24.21 \mathrm{c}$ & $24.16 \mathrm{c}$ & $873 f$ & $867 f$ \\
\hline & & $46.97 \mathrm{~cd}$ & $47.13 \mathrm{~cd}$ & $181.97 \mathrm{~d}$ & $180.4 \mathrm{e}$ & $25.95 \mathrm{bc}$ & $25.72 \mathrm{C}$ & 962de & $946 \mathrm{e}$ \\
\hline & & $47.44 \mathrm{~cd}$ & $47.86 \mathrm{bc}$ & $181.4 \mathrm{~d}$ & 182. & & & 94 & 95 \\
\hline & particles at 0.5 & $48.78 \mathrm{bc}$ & $49.28 \mathrm{~b}$ & $215.77 \mathrm{~b}$ & $204.76 \mathrm{~d}$ & $27.78 \mathrm{~b}$ & $27.24 \mathrm{~b}$ & $953 \mathrm{e}$ & $962 \mathrm{e}$ \\
\hline & & $50.12 \mathrm{~b}$ & $51.34 \mathrm{a}$ & $218.46 \mathrm{~b}$ & $217.62 \mathrm{C}$ & $26.24 \mathrm{~b}$ & $28.58 \mathrm{~b}$ & 100 & $1005 \mathrm{~d}$ \\
\hline \multirow{5}{*}{ 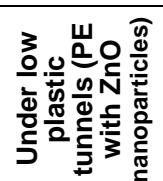 } & y with distilled water) & $46.33 \mathrm{~d}$ & $47.97 \mathrm{bc}$ & $199.52 \mathrm{C}$ & $178.52 \mathrm{e}$ & $24.33 \mathrm{c}$ & $25.33 \mathrm{c}$ & 96 & 973de \\
\hline & $.5 \%$ & $52.59 \mathrm{a}$ & $51.73 \mathrm{a}$ & $239.76 \mathrm{a}$ & $241.42 \mathrm{~b}$ & $30.21 a$ & $31.42 \mathrm{a}$ & 120 & $1225 \mathrm{c}$ \\
\hline & & $52.16 \mathrm{a}$ & & $247.67 \mathrm{a}$ & $248.91 \mathrm{ab}$ & & & 122 & $1234 \mathrm{c}$ \\
\hline & Chitosan nanoparticles at 0.5 & $53.11 \mathrm{a}$ & $53.16 a$ & $253.55 a$ & $255.75 a$ & $31.25 a$ & $31.43 a$ & $1268 b$ & $1289 \mathrm{~b}$ \\
\hline & Chitosan nanoparticles at $1 \%$ & $53.28 \mathrm{a}$ & $53.34 \mathrm{a}$ & $252.44 a$ & $257.75 a$ & $31.18 a$ & $31.44 a$ & $1331 \mathrm{a}$ & $1342 a$ \\
\hline
\end{tabular}

Means of the same column followed by the same letter were not significantly different according to Duncan MRT at $5 \%$.

Table 4: Effects of low plastic-ZnO nano-composite tunnels covering and chitosan nanoparticles foliar spraying on yield and its components of tomato, during the winter seasons of 2012/2013 and 2013/2014.

\begin{tabular}{|c|c|c|c|c|c|c|c|c|c|c|c|}
\hline & \multirow[b]{2}{*}{ Treatments } & \multicolumn{2}{|c|}{$\begin{array}{l}\text { Average fruit } \\
\text { weight (g) }\end{array}$} & \multicolumn{2}{|c|}{$\begin{array}{l}\text { Early yield } \\
\text { (kg/plant)) }\end{array}$} & \multicolumn{2}{|c|}{$\begin{array}{l}\text { Early yield } \\
\text { (ton/fed) }\end{array}$} & \multicolumn{2}{|c|}{$\begin{array}{l}\text { Total yield } \\
\text { (kg/plant) }\end{array}$} & \multicolumn{2}{|c|}{$\begin{array}{c}\text { Total yield } \\
\text { (ton/fed) }\end{array}$} \\
\hline & & $\begin{array}{c}1^{\text {st }} \\
\text { season }\end{array}$ & $\begin{array}{c}2^{\text {nd }} \\
\text { season }\end{array}$ & \begin{tabular}{c|}
$1^{\mathrm{st}}$ \\
season
\end{tabular} & $\begin{array}{c}2^{\text {nd }} \\
\text { season }\end{array}$ & $\begin{array}{c}1^{\text {st }} \\
\text { season }\end{array}$ & $\begin{array}{c}2^{\text {nd }} \\
\text { season }\end{array}$ & $\begin{array}{c}1^{\mathrm{st}} \\
\text { season }\end{array}$ & $\begin{array}{c}2^{\text {nd }} \\
\text { season }\end{array}$ & $\begin{array}{c}1^{\text {st }} \\
\text { season }\end{array}$ & $\begin{array}{c}2^{\text {nd }} \\
\text { season }\end{array}$ \\
\hline \multirow{5}{*}{ 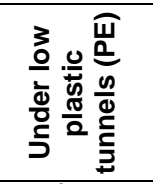 } & $\begin{array}{l}\text { The control treatment (spray with } \\
\text { distilled water) }\end{array}$ & $64.43 \mathrm{~g}$ & $63.82 d$ & $0.222 \mathrm{~g}$ & $0.201 f$ & $5.296 \mathrm{~g}$ & $4.87 \mathrm{~g}$ & $0.582 \mathrm{~d}$ & $0.571 d$ & $8.928 \mathrm{~g}$ & $8.664 \mathrm{~g}$ \\
\hline & Chitosan at $0.5 \%$ & $91.22 \mathrm{e}$ & $90.8 \mathrm{c}$ & $0.299 \mathrm{e}$ & $0.297 \mathrm{~d}$ & $7.132 \mathrm{e}$ & $7.042 \mathrm{e}$ & $0.747 \mathrm{c}$ & $0.731 \mathrm{c}$ & $10.8706 f$ & 10.864ef \\
\hline & Chitosan at $1 \%$ & $98.8 \mathrm{~d}$ & $96.6 \mathrm{c}$ & $0.305 \mathrm{e}$ & $0.301 \mathrm{~d}$ & $7.276 \mathrm{e}$ & $7.208 \mathrm{e}$ & $0.822 \mathrm{c}$ & $0.801 \mathrm{c}$ & $11.670 \mathrm{e}$ & $11.208 \mathrm{e}$ \\
\hline & Chitosan nanoparticles at 0.5 & $111.97 \mathrm{c}$ & $113.7 \mathrm{~b}$ & $0.341 d$ & $0.326 \mathrm{~d}$ & $8.142 \mathrm{~cd}$ & 7.802de & $1.048 \mathrm{~b}$ & $1.031 \mathrm{~b}$ & $15.704 d$ & $15.078 \mathrm{~cd}$ \\
\hline & Chitosan nanoparticles at $1 \%$ & $117.6 \mathrm{~b}$ & $115.3 \mathrm{~b}$ & $0.352 \mathrm{~d}$ & $0.337 \mathrm{~cd}$ & $8.428 \mathrm{c}$ & $8.106 \mathrm{~d}$ & $1.076 \mathrm{~b}$ & $1.064 \mathrm{~b}$ & $15.748 \mathrm{~cd}$ & $15.524 \mathrm{c}$ \\
\hline \multirow{5}{*}{ 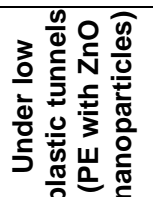 } & $\begin{array}{l}\text { The control treatment (spray with } \\
\text { distilled water) }\end{array}$ & $81.62 f$ & $84.62 c$ & $0.277 f$ & $0.257 \mathrm{e}$ & $6.608 f$ & $6.248 f$ & $0.724 \mathrm{c}$ & $0.711 \mathrm{c}$ & $10.326 f$ & $10.408 f$ \\
\hline & Chitosan at $0.5 \%$ & $123.9 a$ & $125.2 \mathrm{a}$ & $0.349 d$ & $0.348 \mathrm{c}$ & $8.03 \mathrm{~d}$ & $8.112 \mathrm{~d}$ & $1095 b$ & $1.088 \mathrm{~b}$ & $16.204 \mathrm{bc}$ & $16.028 \mathrm{c}$ \\
\hline & Chitosan at $1 \%$ & $125.8 \mathrm{a}$ & $125.6 \mathrm{a}$ & $0.406 \mathrm{c}$ & $0.396 \mathrm{~b}$ & $9.288 \mathrm{~b}$ & $9.428 \mathrm{c}$ & $1.155 \mathrm{~b}$ & $1.124 \mathrm{~b}$ & $16.640 \mathrm{~b}$ & $16.962 \mathrm{~b}$ \\
\hline & Chitosan nanoparticles at 0.5 & $128.4 a$ & $127.9 a$ & $0.437 \mathrm{~b}$ & $0.444 a$ & $10.402 a$ & $10.616 \mathrm{~b}$ & $1.286 \mathrm{a}$ & $1.274 a$ & $19.204 a$ & $19.008 \mathrm{a}$ \\
\hline & Chitosan nanoparticles at $1 \%$ & $128.2 \mathrm{a}$ & $128.1 \mathrm{a}$ & $0.476 \mathrm{a}$ & $0.481 \mathrm{a}$ & $10.204 a$ & $11.462 \mathrm{a}$ & $1.304 a$ & $1.295 \mathrm{a}$ & $19.774 a$ & $19.546 \mathrm{a}$ \\
\hline
\end{tabular}

Means of the same column followed by the same letter were not significantly different according to Duncan MRT at $5 \%$. 
Table 5: Effects of low plastic-ZnO nano-composite tunnels covering and chitosan nanoparticles foliar spraying on quality of tomato fruits, during the winter seasons of 2012/2013 and 2013/2014.

\begin{tabular}{|c|c|c|c|c|c|c|c|c|c|c|c|}
\hline & \multirow{2}{*}{ Treatments } & \multicolumn{2}{|c|}{$\frac{\text { Vitamin C }}{(\mathrm{mg} / 100 \mathrm{~g} \mathrm{FW})}$} & \multicolumn{2}{|c|}{ Acidity } & \multicolumn{2}{|c|}{$\begin{array}{l}\text { Reducing } \\
\text { sugars }\end{array}$} & \multicolumn{2}{|c|}{$\begin{array}{l}\text { Nun-reducing } \\
\text { sugars } \\
\text { (mq/100 q FW) }\end{array}$} & \multicolumn{2}{|c|}{$\begin{array}{l}\text { Total } \\
\text { sugars }\end{array}$} \\
\hline & & $\begin{array}{l}1^{\text {st }} \\
\text { season }\end{array}$ & $\begin{array}{l}2^{\text {nd }} \\
\text { season }\end{array}$ & $\begin{array}{c}1^{\text {st }} \\
\text { season }\end{array}$ & $\begin{array}{l}2^{\text {nd }} \\
\text { season }\end{array}$ & $\begin{array}{c}1^{\text {st }} \\
\text { season }\end{array}$ & $\begin{array}{c}2^{\text {nd }} \\
\text { season }\end{array}$ & $\begin{array}{l}1^{\text {st }} \\
\text { season }\end{array}$ & $\begin{array}{l}2^{\text {nd }} \\
\text { season }\end{array}$ & $\begin{array}{c}1^{\text {st }} \\
\text { season }\end{array}$ & $\begin{array}{l}2^{\text {nd }} \\
\text { season }\end{array}$ \\
\hline \multirow{5}{*}{ 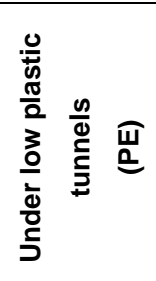 } & $\begin{array}{l}\text { The control treatment (spray with } \\
\text { distilled water) }\end{array}$ & $22.33 c$ & $22.4 d$ & $212.31 \mathrm{e}$ & $211.9 \mathrm{~g}$ & $3.246 f$ & $3.242 \mathrm{e}$ & $1.988 b$ & $1.887 e$ & $5.234 f$ & $5.129 f$ \\
\hline & Chitosan at $0.5 \%$ & $23.24 b$ & $23.13 \mathrm{~cd}$ & $243.11 \mathrm{c}$ & $241.5 \mathrm{e}$ & $3.238 f$ & $3.332 \mathrm{e}$ & $2.051 \mathrm{a}$ & $1.934 \mathrm{cde}$ & $5.289 f$ & $5.266 \mathrm{e}$ \\
\hline & Chitosan at $1 \%$ & $23.16 b$ & $23.2 \mathrm{bc}$ & $254.44 \mathrm{c}$ & $249.8 d$ & $3.477 d$ & $3.481 d$ & $1.983 b$ & $1.944 \mathrm{bcd}$ & $5.46 \mathrm{e}$ & $5.425 d$ \\
\hline & Chitosan nanoparticles at 0.5 & $23.36 b$ & $23.31 \mathrm{bc}$ & $249.55 c$ & $253.7 d$ & $3.652 \mathrm{c}$ & $3.652 \mathrm{c}$ & $1.944 \mathrm{bc}$ & $1.965 \mathrm{bc}$ & $5.596 d$ & $5.617 \mathrm{c}$ \\
\hline & Chitosan nanoparticles at $1 \%$ & $23.48 b$ & $23.5 b c$ & $255.2 \mathrm{c}$ & $258.1 \mathrm{C}$ & $3.734 b$ & $3.714 b c$ & $1.887 \mathrm{~d}$ & $1.979 b c$ & $5.621 d$ & $5.693 c$ \\
\hline \multirow{5}{*}{ 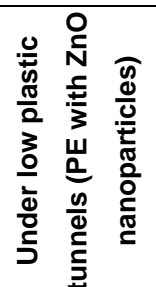 } & $\begin{array}{l}\text { The control treatment (spray with } \\
\text { distilled water) }\end{array}$ & $23.23 b$ & $23.11 \mathrm{~cd}$ & $225.7 d$ & $225.1 f$ & $3.341 \mathrm{e}$ & $3.253 \mathrm{e}$ & $1.934 \mathrm{~cd}$ & $1.907 d$ & $5.275 f$ & $5.16 f$ \\
\hline & Chitosan at $0.5 \%$ & $23.94 b$ & $23.84 b$ & $292.74 b$ & $293.3 b$ & $3.786 \mathrm{~b}$ & $3.797 b$ & $1.911 \mathrm{~cd}$ & $1.917 \mathrm{~d}$ & $5.697 \mathrm{c}$ & $5.704 c$ \\
\hline & Chitosan at $1 \%$ & $23.78 b$ & $23.98 b$ & $294.9 b$ & $295.4 b$ & $3.877 a$ & 3.847ab & $1.965 b$ & $1.988 \mathrm{~b}$ & $5.842 b$ & $5.835 b$ \\
\hline & Chitosan nanoparticles at 0.5 & $24.77 a$ & $24.74 a$ & $309.9 a$ & $297.6 b$ & $3.852 a$ & $3.876 \mathrm{ab}$ & $1.979 b$ & $2.000 \mathrm{a}$ & $5.831 b$ & $5.876 \mathrm{~b}$ \\
\hline & Chitosan nanoparticles at $1 \%$ & $24.83 a$ & $24.79 a$ & $296.22 b$ & $308.6 a$ & $3.937 a$ & $3.925 a$ & $2.003 a b$ & $2.051 \mathrm{a}$ & $5.94 a$ & $5.976 a$ \\
\hline
\end{tabular}

Means of the same column followed by the same letter were not significantly different according to Duncan MRT at $5 \%$. 
Table 6: Economic evaluation of cultivated tomato plants as affected by the combination between low plastic tunnel types and chitosan foliar treatments during the winter seasons of 2012/2013 and 2013/2014.

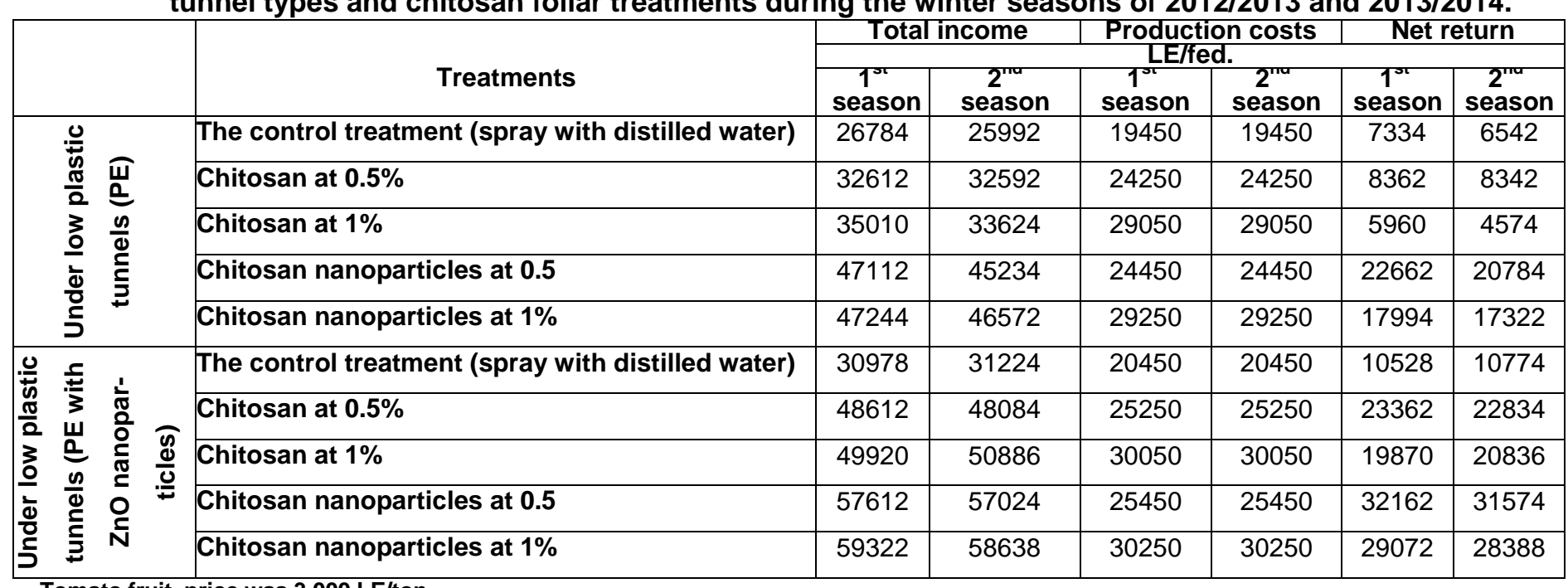

Tomato fruit price was $3,000 \mathrm{LE} /$ ton

Solid yields of tomato fruit in the pest treatments were (19.774and 19.546 ton./fed.) and tomato fruit in the control treatment were (8.928and 8.664 ton/fed.) in 2013 and 2014 seasons, respectively. 
J. Plant Production, Mansoura Univ., Vol. 5 (9), September, 2014 